San Jose State University

SJSU ScholarWorks

Master's Theses

Master's Theses and Graduate Research

1988

\title{
Test of wildlife habitat relationships predictions for the riparian corridor of Guadalupe River San Jose, California
}

Syndie Bachmann Meyer

San Jose State University

Follow this and additional works at: https://scholarworks.sjsu.edu/etd_theses

\section{Recommended Citation}

Meyer, Syndie Bachmann, "Test of wildlife habitat relationships predictions for the riparian corridor of Guadalupe River San Jose, California" (1988). Master's Theses. 3096.

DOI: https://doi.org/10.31979/etd.r98f-e9cs

https://scholarworks.sjsu.edu/etd_theses/3096

This Thesis is brought to you for free and open access by the Master's Theses and Graduate Research at SJSU ScholarWorks. It has been accepted for inclusion in Master's Theses by an authorized administrator of SJSU ScholarWorks. For more information, please contact scholarworks@sjsu.edu. 


\section{INFORMATION TO USERS}

The most advanced technology has been used to photograph and reproduce this manuscript from the microfilm master. UMI films the text directly from the original or copy submitted. Thus, some thesis and dissertation copies are in typewriter face, while others may be from any type of computer printer.

The quality of this reproduction is dependent upon the quality of the copy submitted. Broken or indistinct print, colored or poor quality illustrations and photographs, print bleedthrough, substandard margins, and improper alignment can adversely affect reproduction.

In the unlikely event that the author did not send UMI a complete manuscript and there are missing pages, these will be noted. Also, if unauthorized copyright material had to be removed, a note will indicate the deletion.

Oversize materials (e.g., maps, drawings, charts) are reproduced by sectioning the original, beginning at the upper left-hand corner and continuing from left to right in equal sections with small overlaps. Each original is also photographed in one exposure and is included in reduced form at the back of the book. These are also available as one exposure on a standard $35 \mathrm{~mm}$ slide or as a $17^{\prime \prime} \times 23^{\prime \prime}$ black and white photographic print for an additional charge.

Photographs included in the original manuscript have been reproduced xerographically in this copy. Higher quality $6^{\prime \prime} \times 9^{\prime \prime}$ black and white photographic prints are available for any photographs or illustrations appearing in this copy for an additional charge. Contact UMI directly to order.

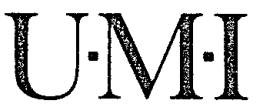



Order Number 1397830

Test of wildlife habitat relationships predictions for the riparian corridor of Guadalupe River, San Jose, California

Meyer, Syndie Bachmann, M.A.

San Jose State University, 1989

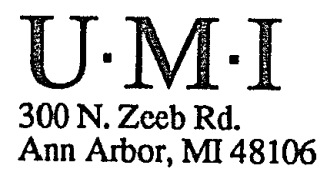





\title{
TEST OF WILDLIFE HABITAT RELATIONSHIPS PREDICTIONS FOR THE RIPARIAN CORRIDOR OF GUADALUPE RIVER SAN JOSE, CALIFORNIA.
}

\author{
A Thesis \\ Presented to \\ The Faculty of the Department of Biological Sciences \\ San Jose State University \\ In Partial Fulfillment \\ of the Requirements for the Degree \\ Master of Arts
}

By

Syndie Bachmann Meyer

August, 1988 
APPROVED FOR THE DEPARTMENT OF BIOLOGICAL SCIENCES

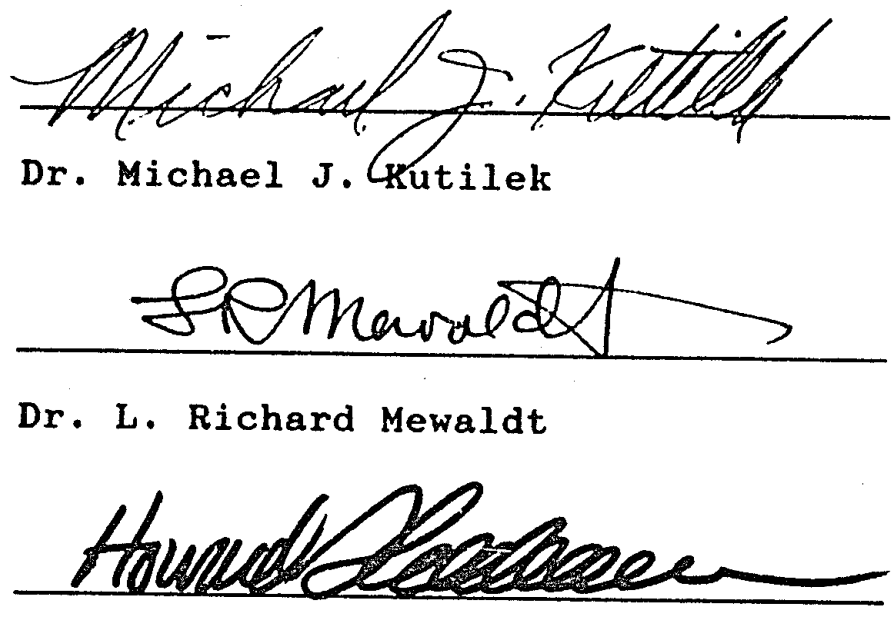

Dr. Howard S. Shell hammer

APPROVED FOR THE UNIVERSITY

Serena w. Stander. 


\section{ACKNOWLEDGMENTS}

I am deeply indebted to M.J. Kutilek, H.S. Shellhammer, and L.R. Mewaldt, Professor Emeritus, of San Jose State University, for their guidance and encouragement during all phases of this study. I am especially grateful for their assistance in editing this paper and for their instruction during data analysis. Dr. Mewaldt also spent many hours improving my ornithological skills.

Thanks also to R.R. Duke and the rest of the Wildlife Division at Harvey and Stanley Associates, Inc. for their assistance and support. Mike Rigney and Rob Klinger were especially helpful during the several difficulties that I encountered with the database and analysis of these data.

This study was partially funded by a grant from Harvey and Stanley Associates, Incorporated who also generously supplied computer time.

Materials and other information which assisted this project were supplied by many individuals. Access to the WHR database was supplied by Dave Ziener who also helped solve various additional access problems. Manuscripts iere supplied by M.L. Avery and C. Van Riper, and by A.S. England and D.W. Anderson. A draft of the WHR user's guide was provided by D. Airola. 
Finally, I would like to thank my family for providing the means to undertake and complete this project. Special thanks are given to Nancy Thurnall, William Meyer, and C.E Roth for their profound contributions. Dan Pappone deserves special commendation for supplying steady nerves, extraordinary wit, and the calm conviction that success was inevitable. 
TABLE OF CONTENTS

Page

ACKNOWLEDGMENTS...................... ii

TABLE OF CONTENTS $\ldots \ldots \ldots \ldots \ldots \ldots \ldots \ldots \ldots \ldots$

LIST OF TABLES........................ vi

LIST OF FIGURES..................... vii

ABSTRACT . .......................... 1

INTRODUCTION........................ 2

STUDY AREA......................... 3

METHods........................... 6

RESULTS.......................... 8

DISCUSSION AND CONCLUSIONS.............. 18

LITERATURE CITED.................... 29 


\section{LIST OF TABLES}

Table

Page

1. List of species which were predicted

by WHR for Valley-Foothill Riparian habitat, or which were observed during sampling of Guadalupe River riparian corridor in 1986... 9 9

2. Species expected but not observed, and probable reasons for their absence from the count or from Guadalupe River corridor during $1986 \ldots \ldots \ldots \ldots \ldots \ldots \ldots \ldots \ldots \ldots \ldots$

3. List of species observed using Guadalupe River corridor during 1986 , but which were not predicted by whR............... 17

4. Modified list of species limited to those species which are most likely to be found in the Guadalupe River corridor. Based on data collected in $1986 \ldots \ldots \ldots \ldots \ldots \ldots \ldots$

5. Summary of how predicted species are expected to use the habitat compared with how observed species have been seen to use Guadalupe River riparian corridor

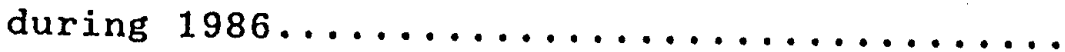




\section{LIST OF FIGURES}

\section{Figure}

Page

1. Location of study area on upper

Guadalupe River, San Jose,

California.. 


\begin{abstract}
Results of a year-long survey of birds in a section of the Guadalupe River riparian corridor in San Jose, Santa Clara County, California were compared to California Department of Fish and Game's "Wildlife and Fish Habitat Relationships" (WHR) predictions for Valley-Foothill Riparian (VFR) Habitat in Santa Clara County. The list produced by WHR contained 131 species of birds, 83 of which were observed during sampling. An additional 33 observed species were not predicted by WHR. While the $38 \%$ error-rate for predictions was not statistically significant, it nevertheless was reduced to $9.5 \%$ as a result of modifying the list to correspond with known features of the study area, and by considering the sampling methods used. The initial list provided information about the possible diversity of bird species in a riparian corridor anywhere in Santa Clara County. Modifications were necessary to produce a list which was accurate for this section of the Guadalupe River. Similar modifications will Frobably be necessary for most other wHR predictions.
\end{abstract}




\section{INTRODUCTION}

California Department of Fish and Game's "Fish and Wildlife Habitat Relationship" (WHR) database contains information about the distribution and habitat requirements of California's 654 vertebrate species. Computer files for each of these were compiled from the available literature and revised through expert reviews. The data may be exiracted in several ways: either by a single specification (vis species, habitat, location, or habitat element), or by a compilation of 2 or more of these specifications (Airola 1986, Salwasser and Laudenslayer 1982).

The accuracy of the system as a predictive model has been tested for chaparral and blue-oak woodland in san Benito County (Avery and Van Riper 1986 unpublished), and chamise-redshank and mixed chaparral in Glenn and Tehama Countics (England and Anderson 1985). Data were collected during 2 or more years in these studies, and the study areas were in relatively undisturbed locations. These. studies showed between $19 \%$ and $25 \%$ error between predicted and observed species, and conclude with recommendations to change the status of a number of species in WHR's matrix model.

This paper compares the results of a one-year survey of birds in a disturbed, bottom-lands, riverine system with the WHR predictions for Valley-Foothill Riparian (VFR) habitat in Santa Clara County. I tested the hypothesis of 
no difference between WHR predictions and species observed during the survey.

\section{STUDY AREA}

The Guadalupe River flows south to north through the bottom lands of Santa Clara Valley from the Guadalupe Creek confluence with Alamitos Creek at the base of Sierra Azul (foothills of the Santa Cruz Mountains) to Alviso Slough (San Francisco Bay) in Alviso. The river is entirely contained within the city limits of the city of San Jose, in Santa Clara County, California. The study area was limited to habitat within and immediately adjacent to the upper 6 miles of river between Interstate Freeway 280 and Blossom Hill Road (Fig.1).

The Guadalupe River drains $420 \mathrm{mi}^{2}$ and is expected to carry 7,500 cubic feet per second (cfs) through the study area in a $1 \%$ event, ie., high flood flows produced by a. combination of meteorological and hydrological events which have 1\% probability of occurring during any storm (U.S. Army Corps of Engineers 1972). The course of the river, its boundaries, floodplains, and surrounding habitat have been altered throughout the history of European man's residence in Santa Clara Valley by the development of land surrounding the river and the implementation of flood- 


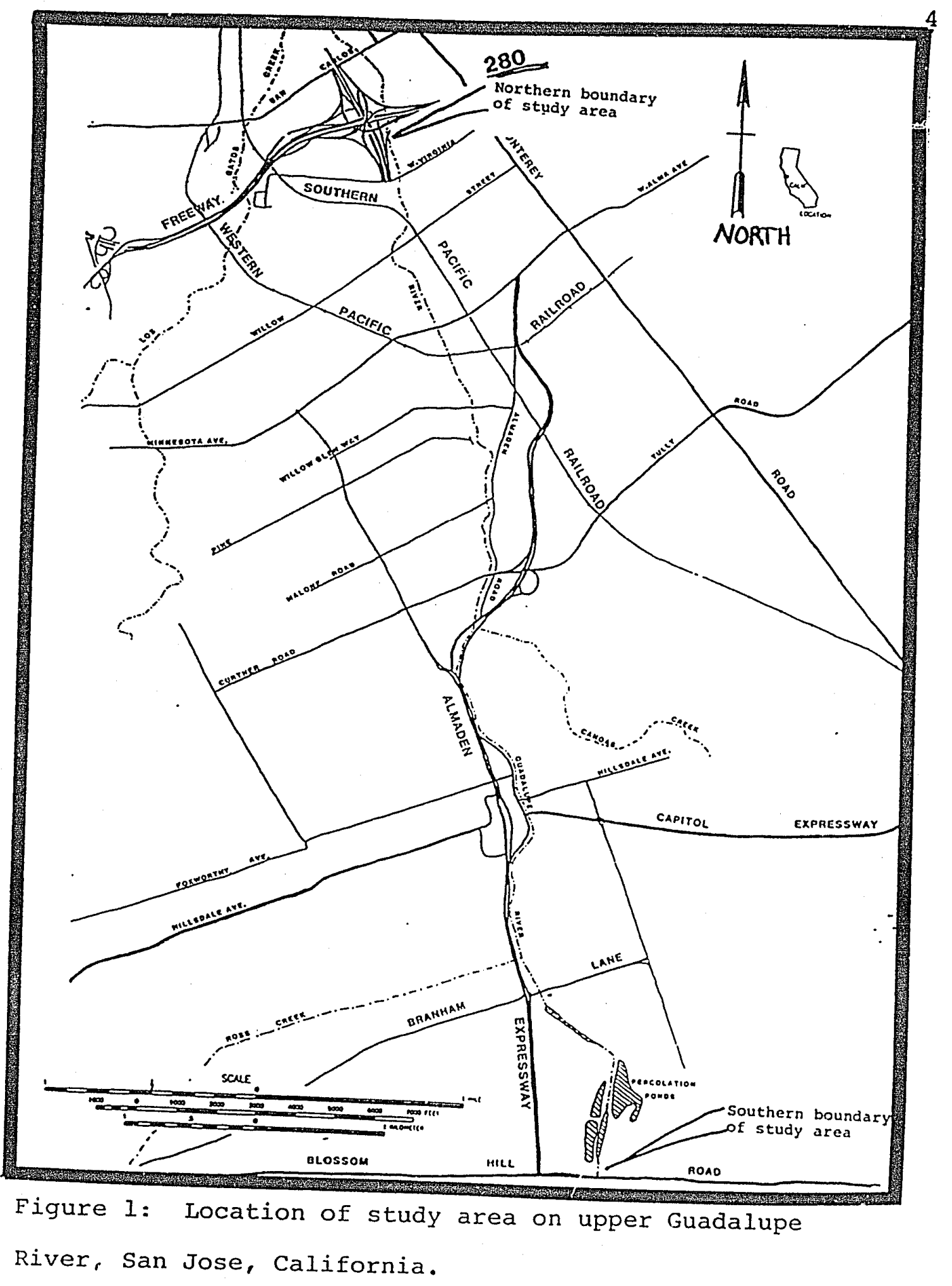


control measures in and around the river channel (U.S. Army Corps of Engineers 1972, 1976, 1985).

Durrenberger (1976) and Lantis et al. (1977) discussed the diversity of weather, topography and plant communities within the "mild-mediterranean" climate of Santa clara County. The influences of two mountain ranges (the Peninsula and Hamilton Ranges of the Coast Range complex), two large bodies of water (the Pacific Ocean and San Francisco Bay), and the complex geology of the region alter this climate to the extent that it supports more than six major plant communities. All of these communities, with the exception of grasslands and riparian associations, are dominated by evergreen trees or shrubs.

Riparian habitats bound rivers and streams throughout the county, but remnants of deciduous riparian corridors may only be found in the broad flatlands of Santa clara Valley (Holstein 1984, Stiles 1978). Riparian corridor forests are Arcto-Tertiary relics of deciduous forests which are well represented only east of the Mississippi River (Chabot and Mooney 1985, Holstein 1984, Vankat 1979). The species composition of corridor forests is distinct from eastern deciduous forests and, in Santa Clara County, is dominated by Fremont cottonwood (Populus fremontii) and western sycamore (Platanus racemosa). The understory of shrubby-trees, shrubs, and ground cover often contains box- 
elder (Acer negundo), walnut ( Juglans spp.), California buckeye (Aesculus californica), valley oak (Quercus lobata), and several types of willow (Salix spp.) (Holland 1986).

The riparian habitat surrounding Guadalupe River has been disturbed during the agricultural, suburban, industrial, and urban activities which have accompanied the development of Santa Clara Valley (U.S. Army Corps of Engineers 1972, 1985). None of the broad forests associated with this type of habitat remain, and the narrow strip of sparse vegetation which still occupies some sections of the corridor has little understory and large proportion of upland species (native or introduced). Among the most common upland species are: Black-locust (Robinia psuedoacacia), California pepper (Shinus molle), elm (Ulmus spp.), English walnut (Juglans regia), eucalypts (Eucalyptus spp.), live oak (Quercus agrifolia), and pine. (Pinus spp.) (Harvey and Stanley, Assoc. 1985, 1986, 1987). The dense understory was largely absent in the study area.

\section{METHODS}

Surveys were conducted by stratified random sampling using modified fixed-radius point (Hutto et al. 1986) and transect counts (Emlen 1971, 1977). Fifty sample areas were selected which represented the range and proportion of 
habitat patch types present within the study area. Habitat patches were defined by WHR size-class and cover-class types for wooded habitats (Salwasser and Laudenslayer 1982). The limits of the corridor were established by property lines (Harvey and Stanley Assoc. 1986) and habitat characteristics, and only birds found within these limits were counted.

Sampling began in January 1986 and continued until January 1987, with repetitions at 14-day intervals throughout the year. Plots were surveyed sequentially using 10-minute samples (Scott 1981). Sampling began each day at dawn and continued until 0930 hours (Robbins 1981). Samples were not taken when the wind speed was greater than $8 \mathrm{mph}$, or when it was raining (Emlen and De Jong 1981, Richards 1981, Robbins 1981).

Counts using visual and auditory cues began immediately upon entering the sample area. Species, type. of cue (sight/sound), number in group, activity, substrate, and indications of vertical and horizontal placement in the vegetation were recorded for each observation. Birds flying over the sample area were not counted, but birds flushed from the site were recorded as were birds flying along the length of the river such as Belted Kingfishers. Care was taken to avoid counting a bird more than once although this method may have resulted in too few birds being counted. 
Weather, time of day, plant phenology, and relative water level were also recorded at each plot.

A list of species was generated by the WHR database which combined all size-class and cover-class categories ("highest habitat") of Valley-Foothill Riparian habitat in the Santa Clara County location. This constituted the list of expected species.

\section{RESULTS}

There were 131 species expected and 116 observed (Table 1). Only 83 species are represented on both lists (expected and observed: EO). The remaining 33 observed species were not predicted by WHR (observed, not expected: ONE), and 48 of the expected species were never observed (expected, not observed: ENO) within the study area.

The predictive 1 ist was $38 \%$ in error, and $29 \%$ of the observed list were species not predicted. Although McNemar's sign test indicated differences this great had a high probability $(p=0.89)$ of being due to chance alone, these error rates seemed high enough that the appropriate next step was to determine whether or not they could be reduced.

Much of the error in predictions made can be corrected by considerations of habitat and the distribution of bird species. Some species may be eliminated from the list if 


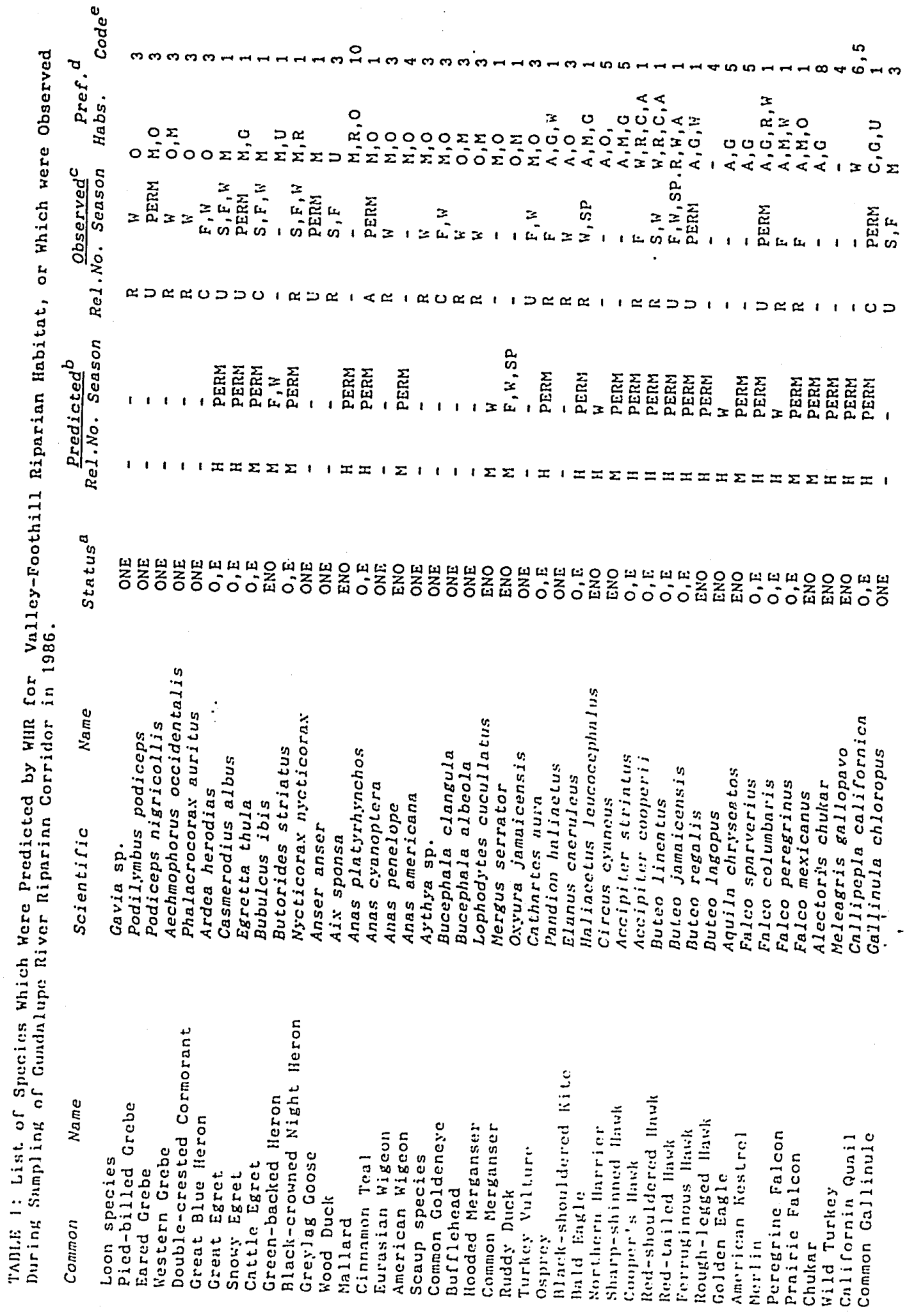



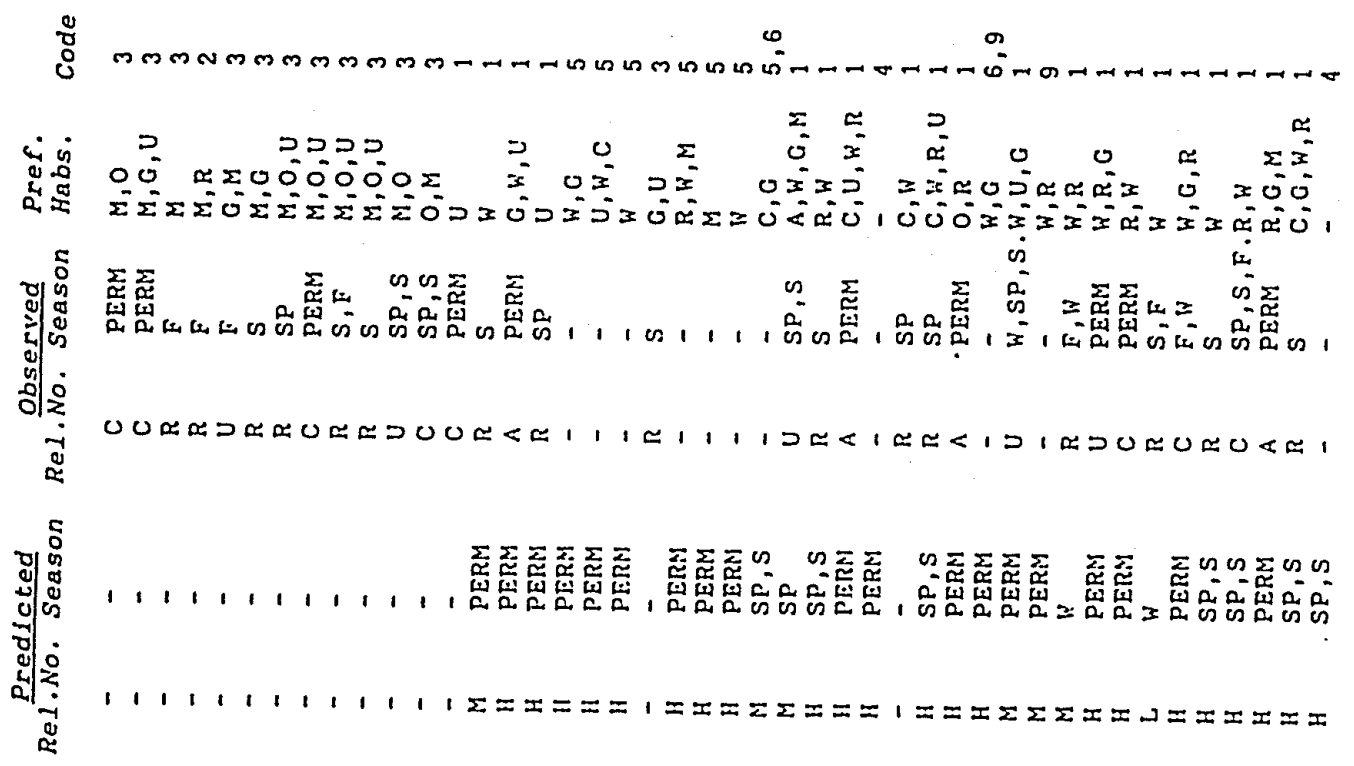

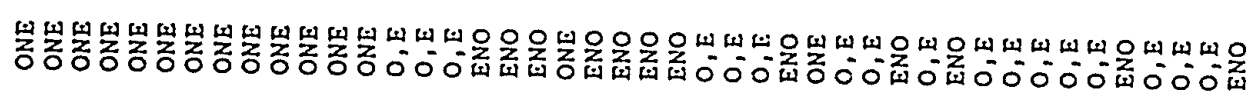
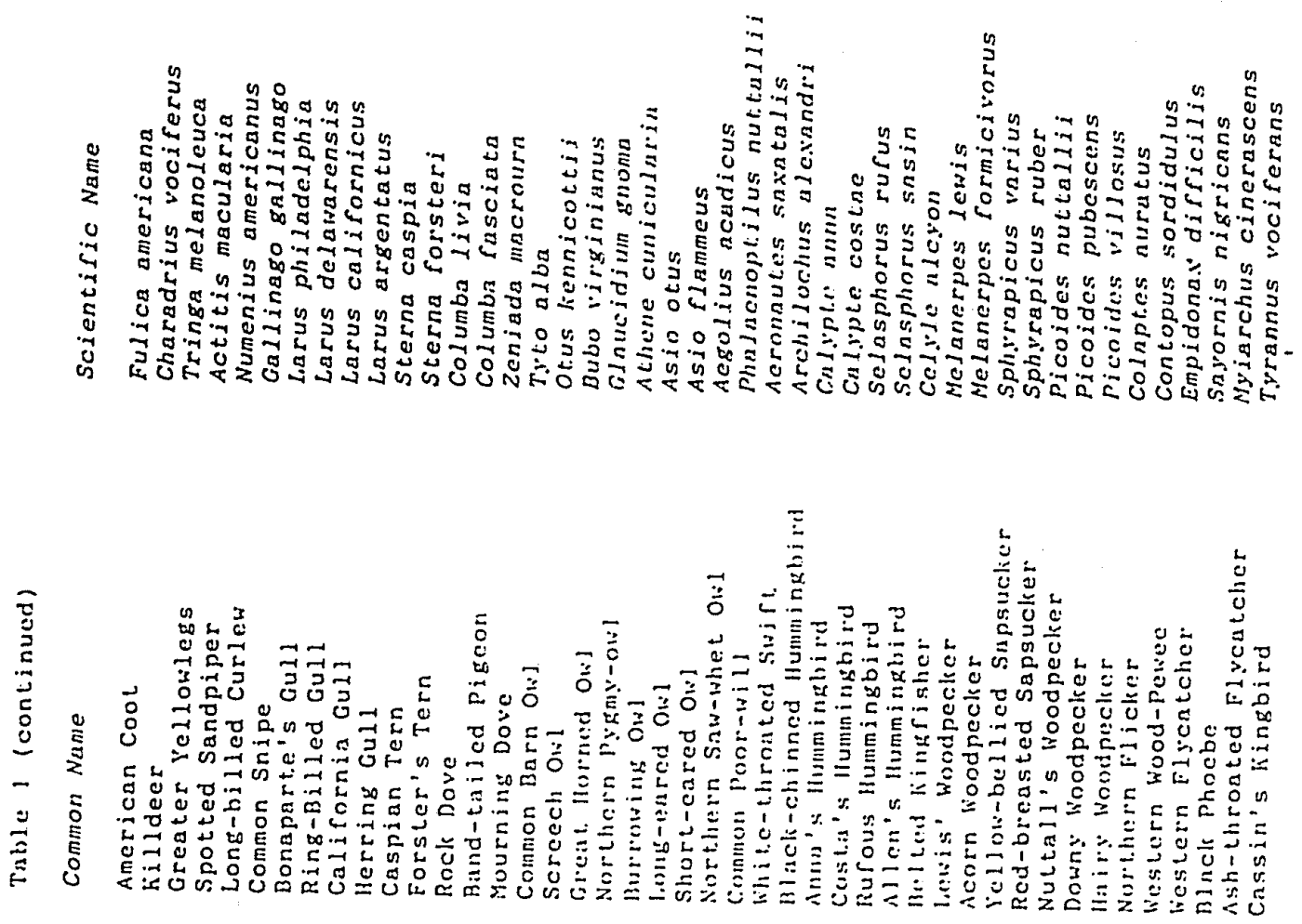

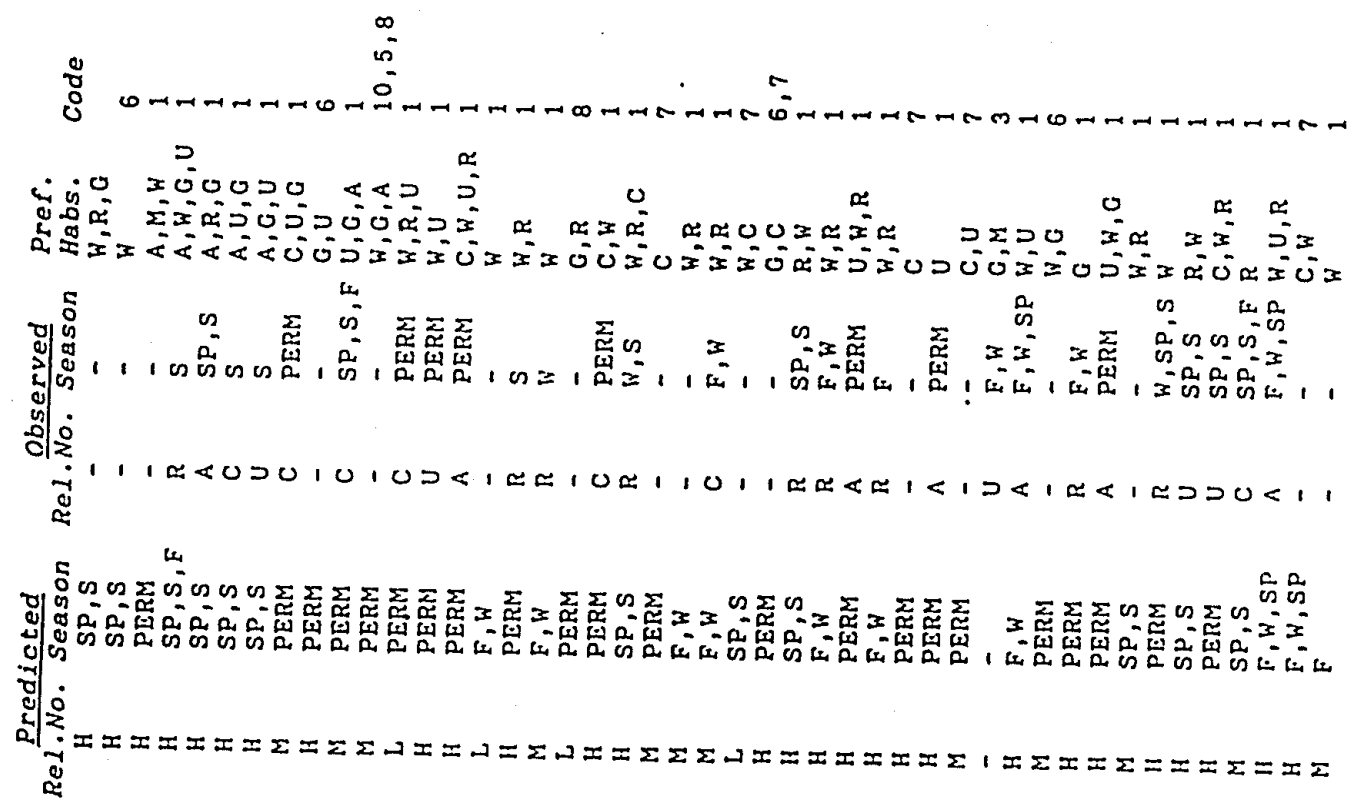

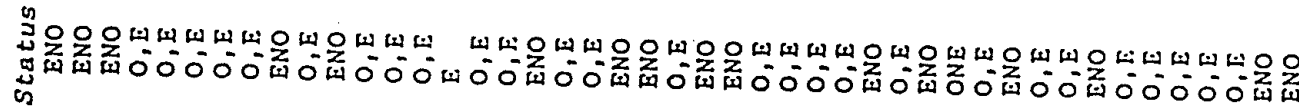
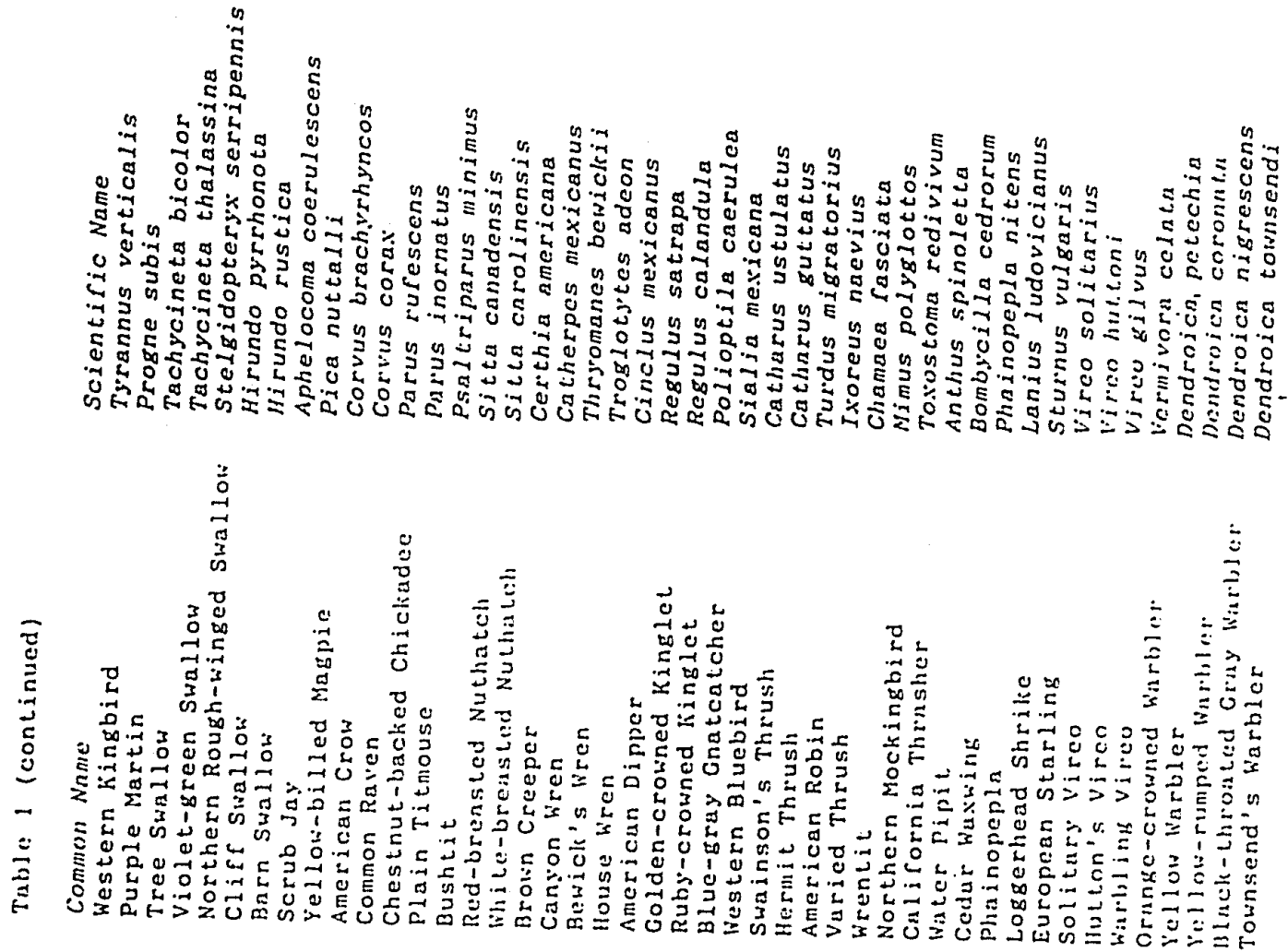

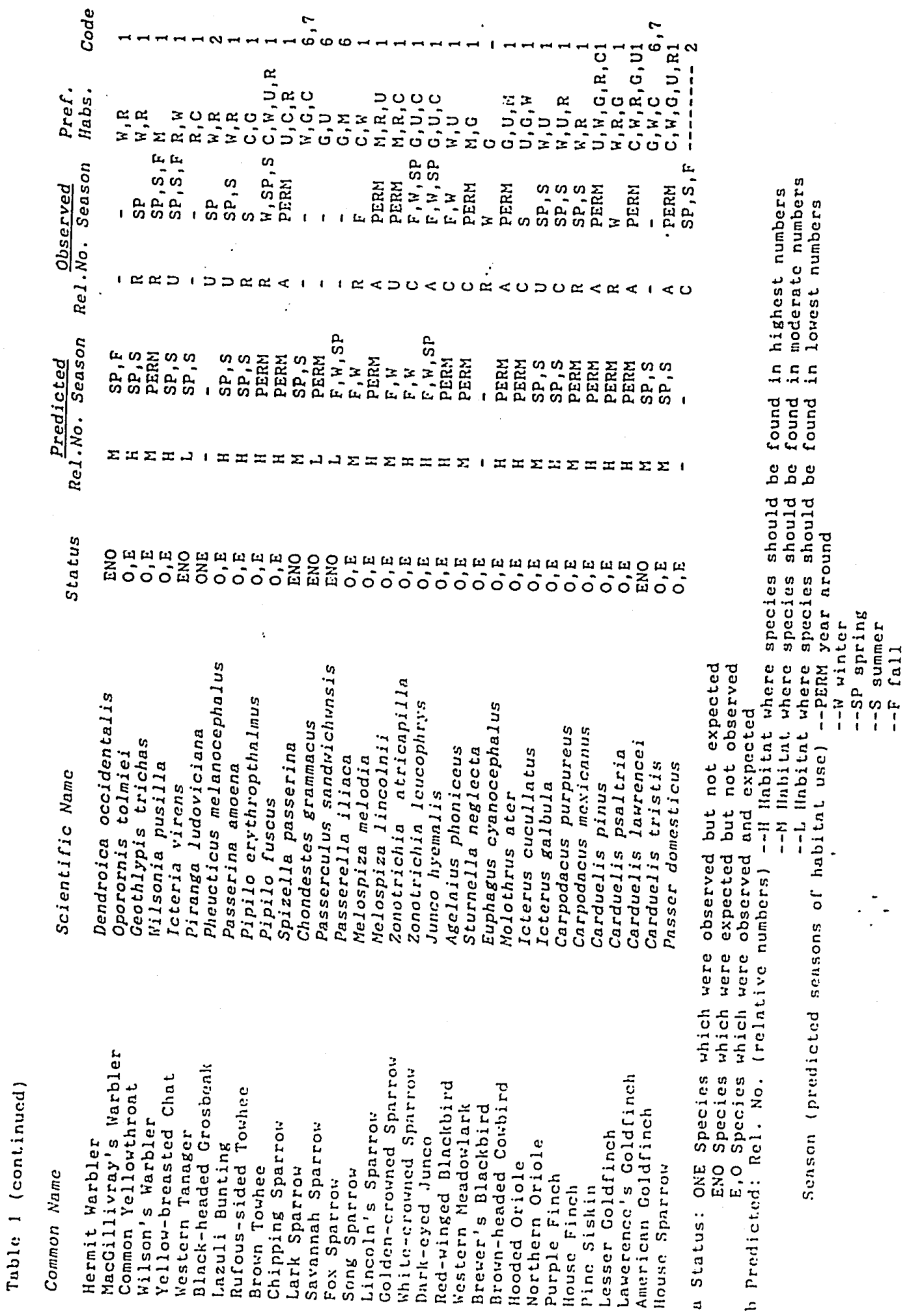


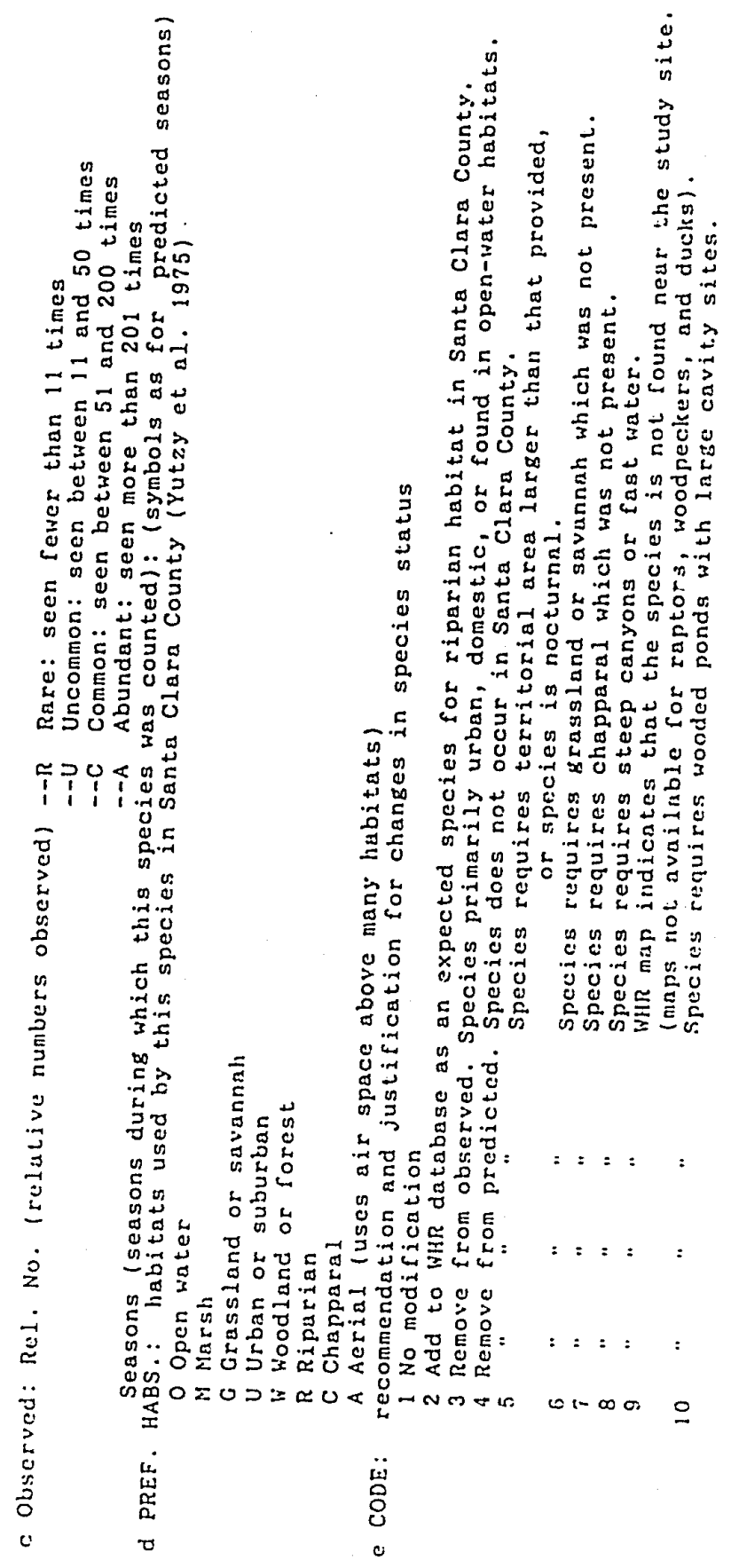


the habitat within the study area does not contain specific elements which they require, or when their distribution does not include the location of the study area. Thirtyfour of the ENO species require habitat elements which are not present in the study area, or additional non-riparian or non-urban habitat adjacent to the riparian corridor (Table 2). Five other species are not found in the county, and the remainder may have been overlooked or not present during this year of study. The latter idea is supported by the fact that 44 of the observed species were seen 10 or fewer times during the 1045 sample periods.

The portion of the error attributable to ONE species was reduced by eliminating species observed only in the percolation ponds adjacent to the Guadalupe River (Table 3). While wooded ponds are part of VFR habitat, the ponds immediately adjacent to Guadalupe River, have barren, gravely banks. Furthermore, the water used to fill these ponds originates from sourcis other than the Guadalupe River. Nineteen ONE species were seen only on the ponds, and 6 others were only seen in the bare areas surrounding them. Of the remaining 8,4 should be added to the list of expected species.

The list of observed and expected species which includes only species expected in habitats similar to the study area, and includes only those portions of the study 
Table 2: Species Expected but not Observed, and Probable Reasons for their Absence from the Count or from Guadalupe River Corridor during 1986 .

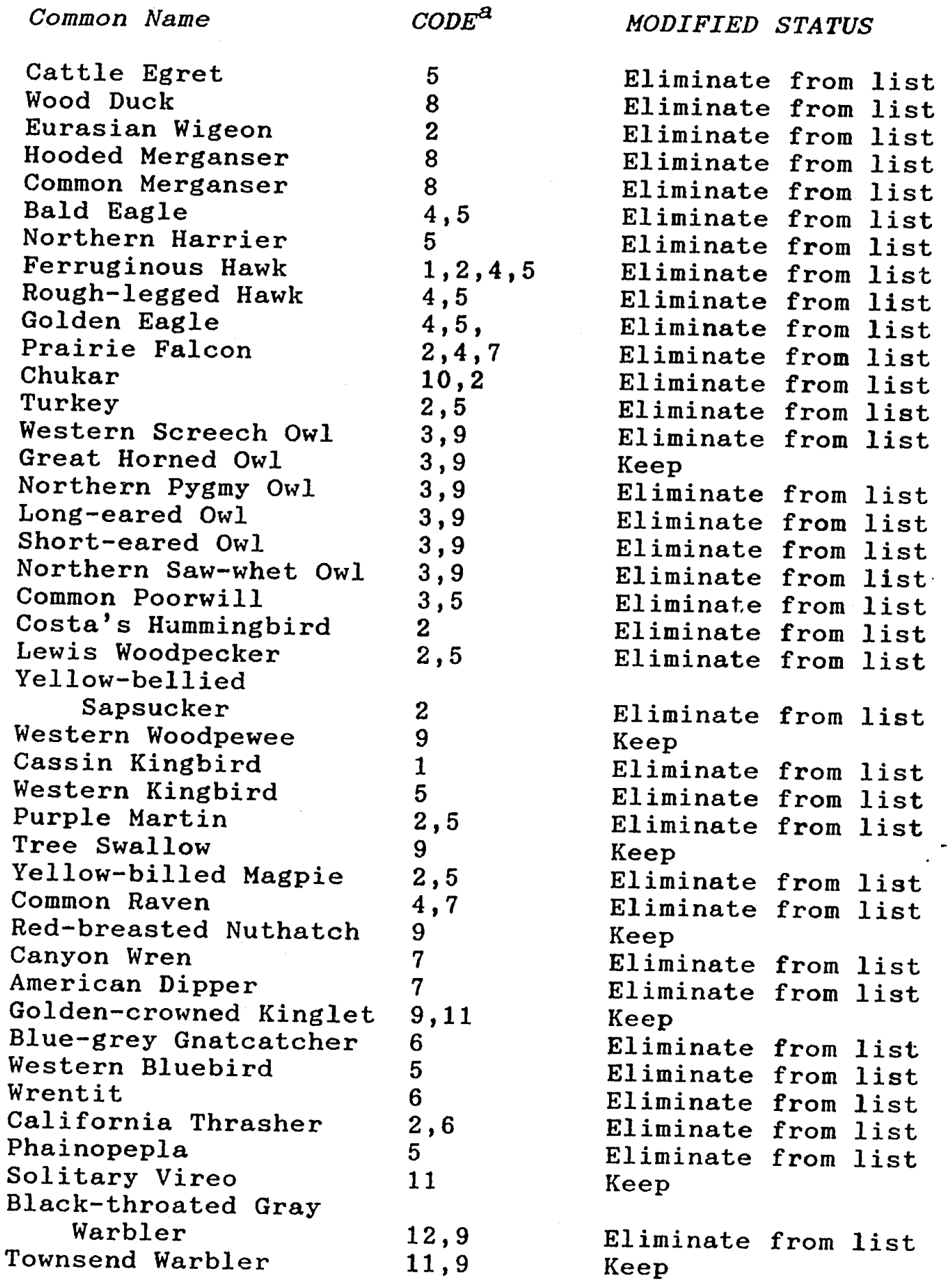


Table 2 (continued)

Common Name

$C O D E^{a}$

MODIFIED STATUS

Hermit Warbler

Yellow-breasted Chat

11,9

12

Chipping Sparrow

Lark Sparrow

6,9

5,9

Savannah Sparrow

5,9

Lawrence Goldfinch

5

Keep
Keep
Eliminate from list
Eliminate from list
Eliminate from list
Eliminate from list

a CODE:

1 Not found in county (Santa Clara County species list)

2 Not found in study area (WHR species maps)

3 Nocturnal

4 Habitat area not large enough to support territory

5 Grassland/savannah not adjacent to riparian habitat

6 Chaparral

7 River not in steep canyon nor on steep slope

8 No wooded ponds nor large nest cavities over water

9 species easily missed or mistaken

10 No rocky slopes adjacent to river

11 No coniferous or mixed coniferous/hardwood forests

12 Insufficient scrub or dense thickets 
Table 3: List of Species Observed Using Guadalupe River Corridor During 1986, but Which Were not Predicted by WHR.

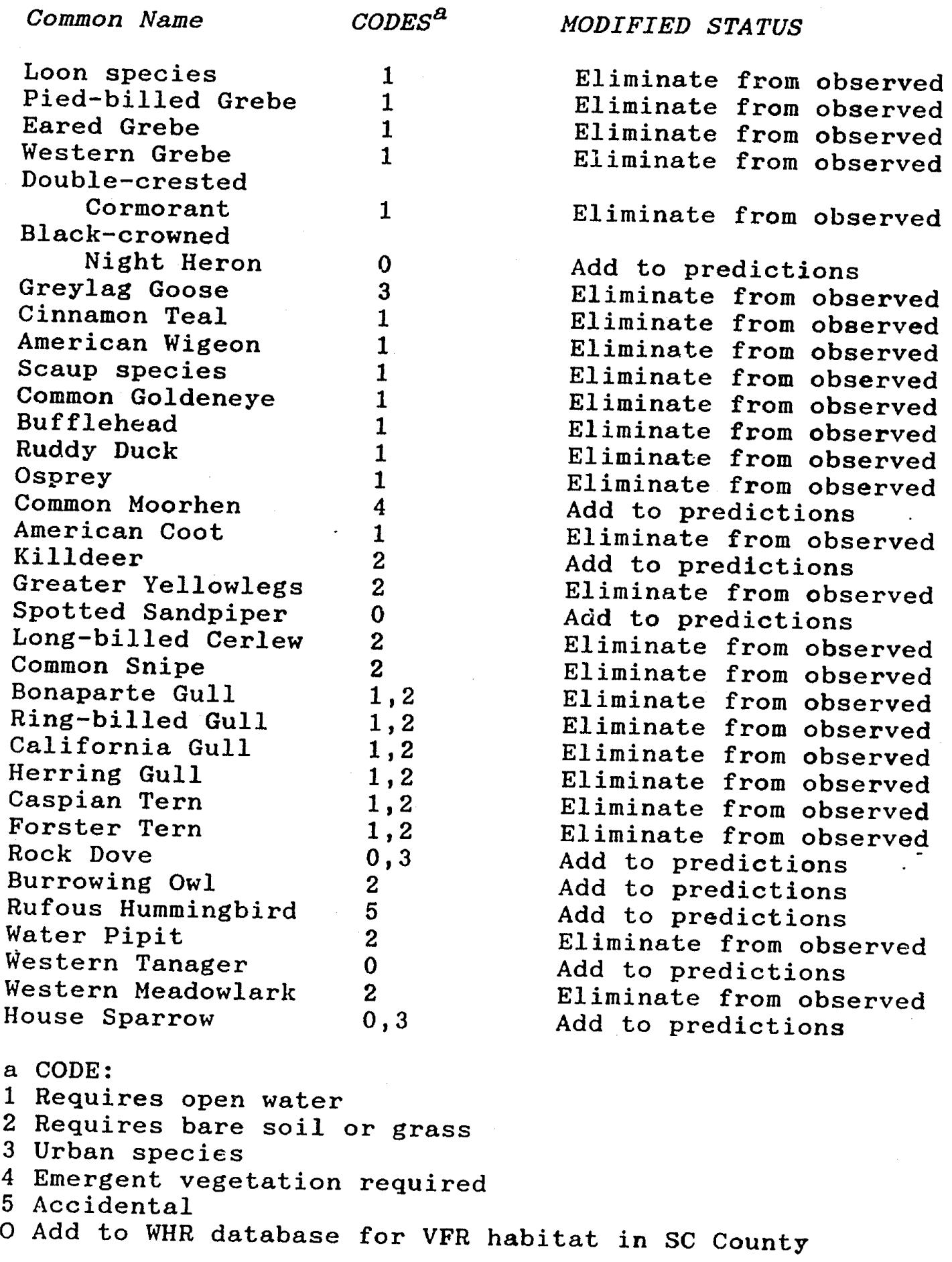


area which are within the banks of the river, has a higher proportion of concurrence than the unmodified list (Table 4). The 6 ONE species and 10 ENO species represent $6.5 \%$ of the observed, and $10.4 \%$ of the expected species, respectively.

Different trends in patterns of use are revealed. when seasonal residency and relative numbers for observed species are compared to the same characteristics for expected species. In the expected species, the permanent residents outnumber the seasonal residents by more than $2: 1$, but more species were observed as residents during the breeding season than were permanent or winter residents. Species expected to have their highest numbers present in VFR habitat accounted for over $58 \%$ of those species in the WHR 1 ist, but fewer than 11 individuals were counted for $37 \%$ of the observed species. Only 19 species had more than 200 individuals counted during the more than 174 hours of. observation.

\section{DISCUSSION AND CONCLUSIONS}

The expected and observed 1 ists were not statistically different from one another, although there was $38 \%$ error in the species predicted. This is a greater error-rate than is normally acceptable for this type of model when it is used as a basis for management decisions. Accuracy of $70 \%$ 
TABLE 4: Modified List of Species Limited to Those species Which are Most Likely to be Found in the Guadalupe Rivar Corridor, Based on Data Collected in 1986.

\begin{tabular}{|c|c|c|}
\hline Common Name & Status ${ }^{a}$ & Code \\
\hline Great Blue Heron & $O, E$ & 1 \\
\hline Great Egret & $0, \mathrm{E}$ & 1 \\
\hline Snowy Egret & $0, E$ & 1 \\
\hline Green-backed Heron & $O, E$ & 1 \\
\hline Black-crowned Night Heron & ONE & 1 \\
\hline Mallard & $\mathrm{O}, \mathrm{E}$ & 1 \\
\hline Turkey Vulture & $0, E$ & 1 \\
\hline Black-shouldered Kite & $0, E$ & 1 \\
\hline Sharp-shinned Hawk & $O, E$ & 1 \\
\hline Cooper's Hawk & $0, E$ & 1 \\
\hline Red-shouldered Hawk & $0, E$ & 1 \\
\hline Red-tailed Hawk & $O, E$ & 1 \\
\hline American Kestrel & $0, E$ & 1 \\
\hline Merlin & $O, E$ & 1 \\
\hline Peregrine Falcon & $\mathrm{O}, \mathrm{E}$ & 1 \\
\hline California Quail & $O, E$ & 1 \\
\hline Common Gallinule & ONE & 3 \\
\hline Killdeer & ONE & 3 \\
\hline Spotted Sandpiper & $0, E$ & 2 \\
\hline Rock Dove & $O, E$ & 1 \\
\hline Band-tailed Pigeon & $\mathrm{O}, \mathrm{E}$ & 1 \\
\hline Mourning Dove & $0, E$ & 1 \\
\hline Common Barn Owl & $0, E$ & 1 \\
\hline Great Horned Owl & ENO & 5 \\
\hline Burrowing Owl & ONE & 3 \\
\hline White-throated Swift & $O, E$ & 1 \\
\hline Black-chinned Hummingbird & $\mathrm{O}, \mathrm{E}$ & 1 \\
\hline Anna's Hummingbird & $\mathrm{O}, \mathrm{E}$ & 1 \\
\hline Rufous Hummingbird & ONE & 1 \\
\hline Allen's Hummingbird & $O, E$ & 1 \\
\hline Belted Kingfisher & $0, E$ & 1 \\
\hline Acorn Woodpecker & $O, E$ & 1 \\
\hline Red-breasted Sapsucker & $0, E$ & 1 \\
\hline Nuttall's Woodpecker & $\mathrm{O}, \mathrm{E}$ & 1 \\
\hline Downy Woodpecker & $\mathrm{O}, \mathrm{E}$ & 1 \\
\hline Hairy Woodpecker & $O, E$ & 1 \\
\hline Northern Flicker & $O, E$ & 1 \\
\hline Western Wood-Pewee & ENO & 1 \\
\hline Western Flycatcher & $O, E$ & 1 \\
\hline Black Phoebe & $0, E$ & 1 \\
\hline Ash-throated Flycatcher & $0, E$ & 1 \\
\hline Tree Swallow & ENO & 1 \\
\hline Violet-green Swallow & $O, E$ & 1 \\
\hline $\begin{array}{l}\text { thern } \\
\text { Rough-winged Swallow }\end{array}$ & $O, E$ & 1 \\
\hline
\end{tabular}


Table 4 (continued)

\begin{tabular}{|c|c|c|}
\hline $\begin{array}{l}\text { Common Nane } \\
\text { Cliff Swallow }\end{array}$ & $\begin{array}{l}\text { Status } \\
\quad \mathrm{O}, \mathrm{E}\end{array}$ & $\begin{array}{c}\text { Code } \\
1\end{array}$ \\
\hline Barn Swallow & $O, E$ & 1 \\
\hline Scrub Jay & $0, E$ & 1 \\
\hline American Crow & $0, E$ & $\overline{1}$ \\
\hline Chestnut-backed Chickadee & $\mathrm{O}, \mathrm{E}$ & 1 \\
\hline Plain Titmouse & $O, E$ & 1 \\
\hline Bushtit & $\mathrm{O}, \mathrm{E}$ & 1 \\
\hline Red-breasted Nuthatch & ENO & 1 \\
\hline White-breasted Nuthatch & $\mathrm{O}, \mathrm{E}$ & 1 \\
\hline Brown Creeper & $\mathrm{O}, \mathrm{E}$ & 1 \\
\hline Bewick's Wren & $O, E$ & 1 \\
\hline House Wren & $O, E$ & 1 \\
\hline Golden-crowned Kinglet & ENO & 1 \\
\hline Ruby-crowned Kinglet & $\mathrm{O}, \mathrm{E}$ & 1 \\
\hline Swainson's Thrush & $0, E$ & 1 \\
\hline Hermit Thrush & $\mathrm{O}, \mathrm{E}$ & 1 \\
\hline American Robin & $0 ; E$ & 1 \\
\hline Varied Thrush & $O, E$ & 1 \\
\hline Northern Mockingbird & $\mathrm{O}, \mathrm{E}$ & 1 \\
\hline Cedar Waxwing & $\mathrm{O}, \mathrm{E}$ & 1 \\
\hline Loggerhead Shrike & $\mathrm{O}, \mathrm{E}$ & 1 \\
\hline European Starling & $O, E$ & 1 \\
\hline Solitary Vireo & ENO & 1 \\
\hline Hutton's Vireo & $O, E$ & 1 \\
\hline Warbling Vireo & $\mathrm{O}, \mathrm{E}$ & 1 \\
\hline Orange-crowned Warbler & $0, E$ & 1 \\
\hline Yellow Warbler & $0, E$ & 1 \\
\hline Yellow-rumped Warbler & $O, E$ & 1 \\
\hline Townsend's Warbler & ENO & 1 \\
\hline Hermit Warbler & ENO & 1 \\
\hline MacGillivray's Warbler & $O, E$ & 1 \\
\hline Common Yellowthroat & $\mathrm{O}, \mathrm{E}$ & 1 \\
\hline Wilson's Warbler & $O, E$ & 1 \\
\hline Yellow-breasted Chat & ENO & 1 \\
\hline Western Tanager & $O, E$ & 2 \\
\hline Black-headed Grosbeak & $\mathrm{O}, \mathrm{E}$ & 1 \\
\hline Lazuli Bunting & $0, E$ & 1 \\
\hline Rufous-sided Towhee & $O, E$ & 1 \\
\hline Brown Towhee & $O, E$ & 1 \\
\hline Fox Sparrow & $O, E$ & 1 \\
\hline Song Sparrow & $O, E$ & 1 \\
\hline Lincoln's Sparrow & $O, E$ & 1 \\
\hline Golden-crowned Sparrow & $O, E$ & 1 \\
\hline White-crowned Sparrow & $O, E$ & 1 \\
\hline Dark-eyed Junco & $O, E$ & 1 \\
\hline Red-winged Blackbird & $O, E$ & 1 \\
\hline Western Meadowlark & ONE & 1 \\
\hline Brewer's Blackbird & $O, E$ & 1 \\
\hline Brown-headed Cowb & $\mathrm{O}, \mathrm{E}$ & 1 \\
\hline
\end{tabular}


Table 4 (continued)

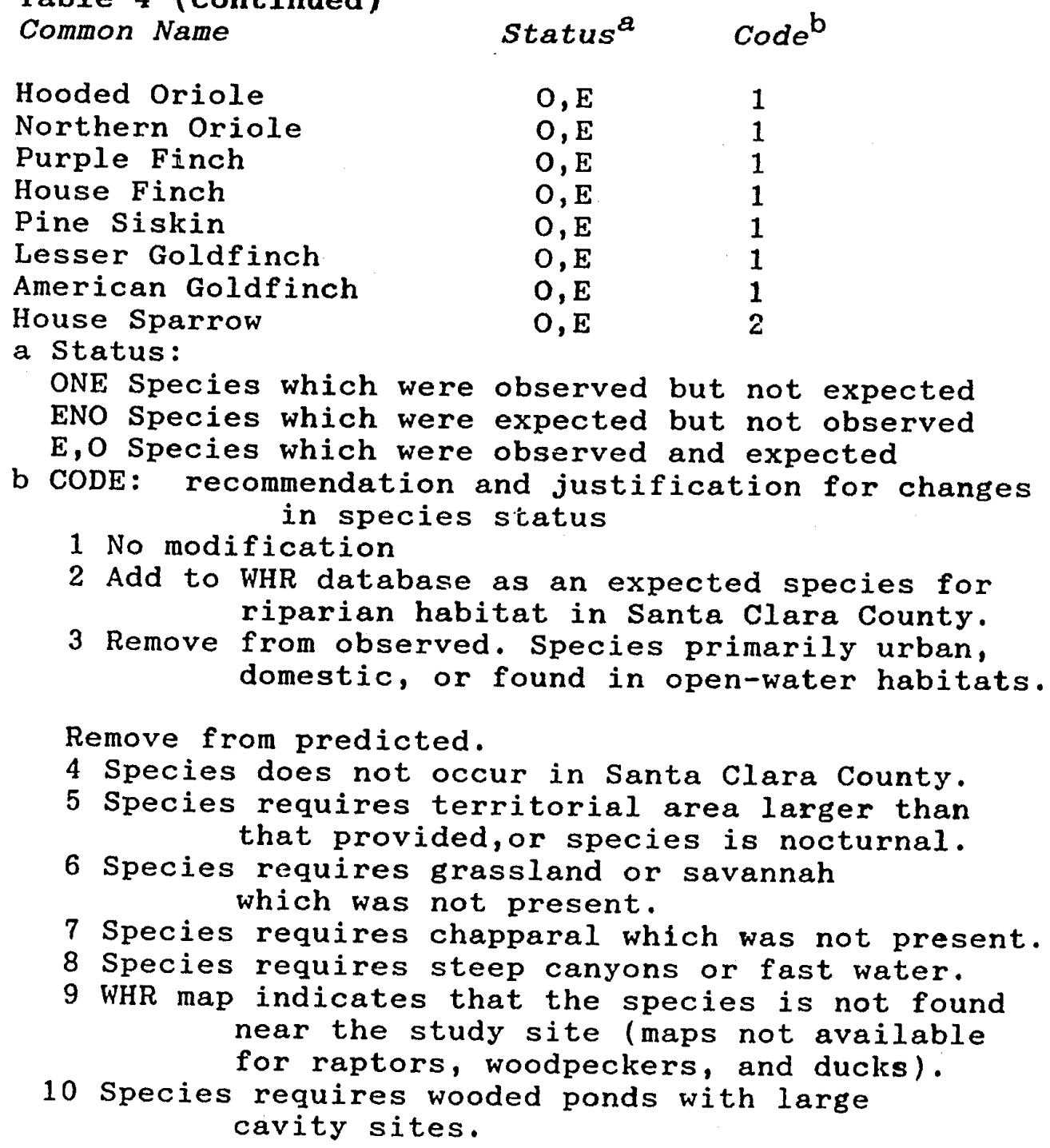

ONE Species which were observed but not expected

ENO Species which were expected but not observed E,O Species which were observed and expected

$b$ CODE: recommendation and justification for changes

1 No modification in species status

2 Add to WHR database as an expected species for riparian habitat in Santa Clara County.

3 Remove from observed. Species primarily urban, domestic, or found in open-water habitats.

Remove from predicted.

4 Species does not occur in Santa Clara County.

5 Species requires territorial area larger than that provided, or species is nocturnal.

6 Species requires grassland or savannah which was not present.

7 Species requires chapparal which was not present.

8 Species requires steep canyons or fast water.

9 WHR map indicates that the species is not found near the study site (maps not available for raptors, woodpeckers, and ducks).

10 species requires wooded ponds with large cavity sites. 
to $75 \%$ is normally considered to be acceptable (Marcot et al. 1984, and Rice et al. 1984). Raphael and Marcot (1986) state that "A model is considered useful if at least some of the model predictions are empirically correct." The utility of any model, including this one, is determined by how readily errors are discovered and by how easily they can be corrected.

The species list produced by WHR provides a generally sound base from which to begin the process of predicting species that will use the riparian habitat. However, there are several species for which the database should be modified. There were four species listed by WHR which are not in the species list for Santa Clara County (Yutzy et al. 1975): the Eurasian Wigeon, Ferruginous Hawk, Chukar, and Cassin's Kingbird. These species should be removed from the database records for this county. Furthermore, there were two observed species (Spotted Sandpiper, Western Tanager) which are commonly seen in riparian areas in the county, but which were not listed in WHR predictions. These two species should be added to WHR for this county: the tanager as a migrant, and the sandpiper as a breeding bird.

Two urban species, Rock Doves and House Sparrows, should be added to the list of expected species. These species thrive in residential and industrial development 
which is prevalent along the river courses throughout the county. They were found throughout the study area and are likely to occur in other riparian zones adjacent to urban and suburban areas.

The adjustments 1 isted above require minimal knowledge of the study site and change the accuracy of the predictions only slightly. Additional modifications, achieved by the elimination of unlikely species and addition of probable species, require a more intimate knowledge of specific elements of the habitat and how individual bird species use these elements. The presence or absence of specific elements, variation in adjacent habitats, and the biases of the sampling methods were used to justify the modifications discussed below.

After inspecting the study area it was apparent that many species would not be found during the sampling (Table 2). Species which require large territories (raptors), . savanah, chaparral, or grassland habitats (many raptors and passerines), steep canyọns (Prairie Falcon, Canyon Wren, American Dipper), or large cavity nest sites overlooking slow water (Wood Duck, mergansers), would be very unlikely on the study site. These species, therefore, were removed from the list of expected species (Table 5). Burrowing Owl, Killdeer, and Western Meadowlark should be added to the list of expected species. These species 
Table 5: Summary of How Predicted Species are Expected to Use the Habitat Compared With How Observed Species Have Been Seen to Use Guadalupe River Riparian Corridor During 1986.

$\begin{array}{lcccc}\text { Variable } & O, E & E N O & \text { ONE } & \text { Total } \\ & - & - & & \\ \text { Expected species } & 83 & 48 & -- & 131 \\ \text { Observed species } & 83 & -- & 33 & 116 \\ \text { Number of species } & 83 & 48 & 33 & 164\end{array}$

WHR PREDICTIONS

\begin{tabular}{|c|c|c|c|c|c|}
\hline Habitat & use High & 52 & 21 & -- & 73 \\
\hline " & Medium & 18 & 17 & -- & 35 \\
\hline$"$ & Low & 2 & 6 & - & 8 \\
\hline Permanent & $t$ Residents & 49 & 27 & -- & 76 \\
\hline Breeding & " & 21 & 9 & - & 30 \\
\hline Winter & " & 12 & 10 & -- & 22 \\
\hline Migrants & & 0 & 1 & -- & 1 \\
\hline
\end{tabular}

OBSERVED SPECIES

\begin{tabular}{|c|c|c|c|c|c|}
\hline$>201$ Coun & t/sp & 19 & -- & 0 & 19 \\
\hline $51--200 "$ & $"$ & 18 & -- & 7 & 25 \\
\hline $11--50$ & $"$ & 16 & -- & 8 & 2 \\
\hline$<11$ & $"$ & 29 & -- & 15 & 44 \\
\hline Permanent & Residents & 28 & - & 5 & 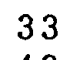 \\
\hline$"$ & Breeding & 33 & -- & 10 & 4 \\
\hline " & Winter & 22 & -- & 14 & 36 \\
\hline Migrants & & 3 & -- & 1 & 2 \\
\hline
\end{tabular}

Species having Riparian Habitat as first

$\begin{array}{lllll}\text { or second preference } & 15 & 10 & 2 & 27\end{array}$

Species Which do Not Prefer

$\begin{array}{lllll}\text { Riparian Habitat } & 39 & 40 & 32 & 111\end{array}$ 
occurred in small areas of gravel and sparse grass adjacent to the river. These were areas where vegetation had not yet recovered or was just beginning to recover after construction activities. Interruptions in the corridor are necessary elements for these species, and are likely to be found in riparian areas elsewhere in Santa Clara County.

Species observed on the percolation ponds adjacent to the Guadalupe River were open water species, not those expected to occupy riparian ponds. Species observed only in this area were removed from the ONE list, because the ponds could not be considered riparian due to the absence of riparian vegetation.

I did not expect to observe owls during the sample periods because of their nocturnal habits. Barn Owls and Great Horned Owls are large enough to be seen occasionally while roosting, and they are also species which use some urban and suburban habitats. For these reasons, all owl species except Barn and Great Horned were eliminated from the list of expected species.

By implementing these changes the error between predictions and observations was reduced by two-thirds to $11 \%$. ONE species make up only $6 \%$ of the remaining list. The remaining ENO species may be attributed to bird community variability between years, species detectibility, skill of the observer, or the fact that the species may not 
occur there. ONE species may be expected when transient species move through the corridor, or when particular habitat elements that are not riparian are located near riparian habitats.

As a general conclusion to this research, it appears that field verification of WHR predictions will have varying success depending upon the size of the area and the length of the study. Larger areas tend to house more species than smaller ones of the same type (Carlquist 1974), and longer studies involving more field hours, more seasons, or more years, will increase the possibility that rare species are observed. Increased effort will also improve the chances of counting species which are difficult to detect.

Seasonal timing also affects the success of field verification. If samples are taken during a single season, or for less than the full compliment of seasons, species which are predicted to use the habitat during the remaining seasons are much less likely to be observed. Birds which are quite conspicuous during the breeding season are often difficult to locate during migration or while they occupy their winter habitat. Conversely, birds which gather in large flocks during the fall and winter are much more visible than during other seasons.

The value of the WHR database appears to be not in its 
precision, but in its versatility. It provides an extensive list of species, most of which will probably occur in the particular habitat or geographic location under study. Special geologic, and geographic characteristics of the study area, the quality of vegetation, and the specific qualities of the surrounding habitats may require some modification of the list beyond the resolution of the database as was the case here. In this study, a modified list was produced by taking into account the particular character of the Guadalupe River corridor and its adjacent habitats.

Future use of WHR predictions for VFR habitat in Santa Clara County, and probably for most habitats in California, will require adjustments to the list to reflect the unique qualities of each area. Most adjustments may be made after reviewing the predictions and inspecting the site for those particular habitat elements which would be required by the predicted species. If certain characteristics are absent from the site or the adjacent areas, species associated with those characteristics can not be expected to occur with any regularity. If these species are of special interest, specific studies may be necessary to determine their status.

I conclude that WHR predictions are generally useful and appropriate. The database produced a list which 
included nearly all avian species which were likely to inhabit the study area. Beyond this it is the responsibility of the researcher or agency to modify the list to reflect the level of accuracy appropriate to the project at hand. 
Airola, D. 1986. (Draft) Users guide for the California Wildife Habitat Relationships system. in preparation for California Department of Fish and Game. $135 \mathrm{pp}$.

Avery, M.L., and C. Van Riper III. 1986. Evaluation of Wildlife-Habitat Relationships database for predicting bird community composition in chaparral and blue oak woodland. (manuscript) $235 \mathrm{pp}$.

Chabot, B.F., and H.A. Mooney. 1985. Physiological ecology of North American plant communities. Chapman and Hall, New York. $351 \mathrm{pp}$.

Carlquist, S. 1974. Island Biology. Columbia University Press, New York. $660 \mathrm{pp}$.

Durrenberger, R.W., and R.B. Johnson. 1976. California: patterns on the land. 5th ed. Mayfield Publishing Company, Palo Alto, California. $134 \mathrm{pp}$.

Emlen, J.T. 1971. Population densities of birds derived from transect counts. Auk 88:323-342.

- 1977. Estimating breeding season bird densities from transect counts. Auk 94:455-468.

Emlen, J.T.; M.J. De Jong. 1981. The application of song detection threshold distance to census operations. Ralph, C.J; Scott, J.M; (Eds.). Estimating numbers of terrestrial birds. Cooper Ornith. Soc. Studies in Avian Bio. (6):346-352.

England, A.S., and D.W. Anderson. 1985. Avian community . ecology in Northern California chaparral: evaluation of wildlife-habitat relationship matrix models for chamise-redshank and mixed chaparral. prepared for USDA For. Ser. Pac. Southwest For. and Range Expe. Sta. (manuscript). $250 \mathrm{pp}$.

Harvey and Stanley, Associates. 1987. Guadalupe River baseline investigation. Prepared for Santa Clara Valley Water District. 42 pp.

Holland, R.F. 1986. Preliminary descriptions of the terrestrial natural communities of California. State Game. $156 \mathrm{pp}$. 
Holstein, G., 1984. California riparian forests: deciduous islands in an evergreen sea. Warner, R.E; Hendrix, K.M. (Eds.) California riparian systems: ecology, conservation, and protective management. University of California Press, Berkeley. 1035 pp. (pp.2-22).

Hutto, R.L., S.M. Pleschet, and P. Hendricks. 1986. A fixed-radius point count method for breeding and nonbreeding season use. Auk 105:593-60z.

Lantis, D.W., R.Steiner, and A.E.Karinen. 1977. California: land of contrast. 3rd ed. Kendall/Hunt Publishing Company, Dubuque, Iowa. $486 \mathrm{pp}$.

Marcot, B.G., M.G. Raphael, and K.H. Berry. 1983. Monitoring wildife habitat and validation of wildlife-habitat relationships models. Trans. No. Amer. Wild. Nat. Res. Confer. 48:315-329.

Raphael, M.G.; B.G. Marcot. 1986. Validation of a wildlife habitat-relationships model: vertebrates in a douglas-fir sere. In: Verner, J.M.; Morrison, M.L.; Ralph, C.J., eds. Wildlife 2000: modeling habitat relationships of terrestrial vertebrates. University of Wisconsin Press, Madison. p.129-138.

Rice, J.C.; R.D. Ohmart; B.W. Anderson. 1984. Limits in a data-rich model: modeling experience with habitat management on the Colorado River. In: Verner, J.; Morrison, M.L.; Ralph, C.J., eds. Wildlife 2000: modeling habitat relationships of terrestrial vertebrates. University of Wisconsin Press, Madison. p. 79-86.

Richards, D.G. 1981. Environmental acoustics and censuses of singing birds. Ralph, C.J.; Scott, J.M. (Eds.). Estimating numbers of terrestrial birds. Cooper Ornith. Soc. Studies Avian Bio. (6):297-300.

Robbins, C.S. 1981a. Effect of time of day on bird activity. Ralph, C.J.; Scott, J.M. (Eds.). Estimating numbers of terrestrial birds. Cooper Ornith. Soc. Studies Avian Bio. (6):275-286.

Robbins, C.S. $1981 \mathrm{~b}$. Bird activity levels related to weather. Ralph, C.J.; Scott, J.M. (Eds.). Estimating numbers of terrestrial birds. Cooper Ornith. Soc. Studies Avian Bio. (6):301-310. 
Salwasser, H., and W.F. Laudenslayer, Jr. 1982. California Wildlife and Fish Habitat Relationships System: products and standards for wildlife. Calif. Int. age. Wild. Task Gr. USDA For. Ser. Pac. Southwest R. $46 \mathrm{pp}$.

Scott, J.M., and F.L. Ramsey. 1981. Length of count period a possible source of bias in estimating bird densities. Ralph, C.J.; Scott, J.M. (Eds.). Estimating numbers of terrestrial birds. Cooper Ornitin. Soc. Studies Avian Bio. (6):409-413.

Stiles, W.A. 1978. Valley riparian forests of California: an overview of their biological significance and physical/chemical processes. Santa Clara Valley Water District. $38 \mathrm{pp}$.

U.S. Army Corps of Engineers. 1972. Flood plain information: Guadalupe River, Santa Clara County, California. prepared for Santa Clara County Flood Control and Water District. $18 \mathrm{pp}$.

- 197.6. Information brochure: alternative proposals for flood control and allied purposes, Guadalupe River, San Jose, California. $42 \mathrm{pp}$. - 1985. Final Guadalupe River interim feasibility report and environmental impact statement: Guadalupe River and adjacent streams investigation, Santa Clara County, California. 1035pp.

Vankat, J.L. 1979. The natural vegetation of North America: an introduction, John Wiley and Sons, New York. 261 $156 \mathrm{pp}$.

Yutzy, R., M. Brady, and H.G. Weston Jr.. 1975. Checklist of the birds of Santa Clara County. Santa Clara Valley Audubon Society. 8pp. 